\title{
Biomass increment and carbon balance of ash (Fraxinus excelsior) trees in an experimental stand in northeastern France
}

\author{
Noël Le GOFFa*, André GRANIER ${ }^{\mathrm{b}}$, Jean-Marc OTTORINI ${ }^{\mathrm{a}}$, Marianne PEIFFER ${ }^{\mathrm{b}}$ \\ ${ }^{a}$ LERFoB, UMR INRA/ENGREF, Équipe Croissance et Production, INRA Centre de Nancy, 54280 Champenoux, France \\ b EEF, UMR INRA/UHP, Équipe Bioclimatologie et Écophysiologie, INRA Centre de Nancy, 54280 Champenoux, France
}

(Received 22 July 2002; accepted 8 March 2004)

\begin{abstract}
In this study, we compared the annual biomass increment of ash trees to their annual carbon balance calculated from the end of the growing season in 1994 to the end of the next one in 1995. In 1995, three trees of variable competitive status and aged 25 were studied. Stem, branch and root biomass increments were derived from detailed measurements. Tree crowns were divided vertically into three layers. In each crown layer, the foliage biomass and area were determined, net $\mathrm{CO}_{2}$ assimilation $\left(A_{n}\right)$ and global radiation $\left(R_{g}\right)$ were measured regularly throughout the growing season. Outside this period, $R_{g}$ was estimated from global radiation measured above the canopy and from estimations of light transmittance. Net assimilation of trees $\left(A_{N}\right)$ was obtained by scaling leaf $A_{n}$ to the tree level, using relations established between $A_{n}$ and $R_{g}$ for each crown layer, the distribution of foliage area, and measured climatic data. Above- and below-ground tree respirations, not measured, were estimated. $A_{n}$ was correlated to $R_{g}$ and potential evapotranspiration. It decreased from the upper to the lower crown layers, but was independent of tree competitive status. Total estimated respiration of trees accounted for about $37 \%$ of gross assimilation. The proportion of carbon allocated to the stem was more than $45 \%$. Net productivity of trees obtained from simulated annual carbon fluxes compared reasonably well with the biomass increment of trees.
\end{abstract}

biomass partitioning / carbon assimilation / respiration / scaling / leaf area

Résumé - Accroissement en biomasse et bilan de carbone du frêne dans un peuplement expérimental du nord-est de la France. Cette étude avait pour but de comparer l'accroissement annuel en biomasse de frênes à leur bilan de carbone établi par estimation de la photosynthèse et de la respiration sur une année complète (depuis la fin de la saison de végétation 1994 à la fin de celle de 1995). En 1995, trois frênes de différents statuts concurrentiels âgés de 25 ans ont été étudiés. Les accroissements en biomasse de la tige, des branches et des racines ont été obtenus à partir de mesures détaillées. Les houppiers des arbres ont été divisés verticalement en trois strates. Pour chaque strate, les variables suivantes ont été mesurées: la biomasse et la surface foliaires, la photosynthèse et le rayonnement global $\left(R_{g}\right)$ pendant la période de croissance. En dehors de cette période, le rayonnement global a été estimé à partir du rayonnement global hors couvert et de valeurs estimées de la transmittance pour chaque strate. L'assimilation nette des arbres $\left(A_{N}\right)$ a été obtenue en extrapolant l'assimilation nette foliaire $\left(A_{n}\right)$ à partir des relations établies entre $A_{n}$ et $R_{g}$ pour chaque strate du houppier, de la distribution du feuillage par strate et des données climatiques mesurées. La respiration des arbres, non mesurée, a été estimée. L'assimilation nette $A_{n}$ est liée à $R_{g}$ et à l'évapotranspiration potentielle et décroît du haut vers le bas du houppier; elle est indépendante du statut concurrentiel des arbres. La respiration totale des arbres représente environ $37 \%$ de leur assimilation brute annuelle. La proportion de carbone allouée à la tige représente en 1995 plus de $45 \%$ du carbone total stocké par les arbres. Le bilan de carbone des arbres obtenu par estimation des flux de carbone est en assez bon accord avec leur accroissement en biomasse.

répartition de la biomasse / assimilation carbonée / respiration / changement d'échelle / surface foliaire

\section{INTRODUCTION}

Few studies have attempted to compare the net primary productivity (NPP) of trees and carbon uptake resulting from photosynthesis and respiration. Most efforts have been made at the stand level by estimating net ecosystem carbon exchange from eddy flux measurements $[1,16,31]$. The latter technique can also be used to estimate $\mathrm{CO}_{2}$ fluxes in individual trees by scaling down stand flux measurements, if the contribution of the understorey component (herbaceous plants, mosses, lichens, ...) to the fluxes is negligible. This was done, for example, to estimate tree respiration [24]. Leaf $\mathrm{CO}_{2}$ assimilation has been studied extensively by considering its variation in tree crowns or in the canopy. Several such studies were conducted to scale carbon fluxes from leaf to stand or canopy level $[2,15,19]$, but few attempts have been made, for forest trees, to derive net assimilation by scaling up leaf measurements [24, 34].

Any attempt to compare tree NPP and carbon uptake must consider all tree compartments, including the root system, even if it contributes less than the above-ground compartments to

\footnotetext{
* Corresponding author: le_goff@nancy.inra.fr
} 
tree NPP [1, 24, 25, 40]. Root turnover should also be considered [20], but it is difficult to estimate. Annual biomass increment should be estimated from measurements of the stem, branches and roots of the trees under study. In addition, the amount and distribution of leaf area control radiation interception by tree crowns and determine carbon assimilation as the balance between photosynthesis and respiration [5].

During the period 1993-1996, we studied the growth of a sample of ash trees of different competitive status, and were able to relate bole volume increment to foliage biomass [26]. Moreover, during year 1995, ecophysiological and microclimatic measurements were performed to analyze the photosynthesis of a sub-sample of these ash trees in relation to their water status. The present study is an attempt to compare yearly biomass increment and carbon balance derived from $\mathrm{CO}_{2}$ flux measurements, for ash trees. The aims of the study were: (i) to estimate the annual biomass increments of the different tree compartments (stem, branches and roots); (ii) to establish radiation-response curves allowing to scale up leaf photosynthesis to tree level; (iii) to estimate carbon fluxes for each tree (net assimilation, respiration and carbon balance) using the established relations, the distribution of foliage area per crown layer and microclimatic data; and, (iv) to compare the biomass increments and carbon balances of the study trees.

\section{MATERIALS AND METHODS}

\subsection{Site}

The study was conducted in the state forest of Amance, in the northeast of France, $15 \mathrm{~km}$ east of Nancy ( $48^{\circ} 44^{\prime} \mathrm{N}, 6^{\circ} 14^{\prime} \mathrm{E}$; altitude $\left.250 \mathrm{~m}\right)$. The main characteristics of the site (soil and climate) and the main features of the experimental stand of trees have been already described [26]. Briefly, the climate is semi-continental with a mean annual temperature and total annual precipitation of $9.2^{\circ} \mathrm{C}$ and $750 \mathrm{~mm}$, respectively. The topography is relatively flat, with a gentle slope to the south. The parent material is lime marl covered by a loam layer 45$50 \mathrm{~cm}$ deep. A calcareous layer is present at depths varying from $85 \mathrm{~cm}$ in the lower part of the experimental plot to $165 \mathrm{~cm}$ in the upper part. Moreover, the soil is rich in clay: the percentage of clay is at least $35 \%$ in all the soil layers, and exceeds $60 \%$ in $B$ layers. The stand, developed after a clear-cut in 1970, mainly consisted of even-aged ash trees (Fraxinus excelsior L.) mixed with some other broad-leaved species of the same age; almost no understorey was present underneath.

\subsection{Study trees}

Three trees were used for the present study (identified herein as trees 6,10 , and 12), representing the range of competitive status in a larger experiment involving 17 ash trees [26]. The competitive status of the trees, measured by the ratio of crown length (distance between crown base and tree apex) to total height varied from 0.3 to 0.6 for the 17 ash trees. The crown ratios and the main characteristics of the three study trees, measured after the 1994 growing season, are given in Table I.

Two scaffoldings provided access to the crowns for detailed growth and ecophysiological measurements in 1995 . Trees 10 and 12 were located in the high slope part of the stand and tree 6 was in the low slope part.

The trees were approximately 25 years old in 1995 when measurements were taken for this study. The crown projection area $\left(A_{c}\right)$ was
Table I. Main characteristics of the three ash trees measured in autumn 1994 and subjected to detailed growth and ecophysiological analyses in 1995.

\begin{tabular}{lccc}
\hline \multirow{2}{*}{ Characteristics } & \multicolumn{3}{c}{ Tree number } \\
\cline { 2 - 4 } & 6 & 10 & 12 \\
\hline DBH $(\mathrm{cm})$ & 18.2 & 12.8 & 9.7 \\
Height $(\mathrm{m})$ & 17.1 & 14.8 & 14.9 \\
Crown ratio* & 0.51 & 0.32 & 0.39 \\
Crown projection area $\left(\mathrm{m}^{2}\right)$ & 11.1 & 5.63 & 2.69 \\
Foliar biomass $\left(B_{f}\right)(\mathrm{kg}, \mathrm{dry})$ & 4.47 & 1.85 & 0.80 \\
LAI $\left(\mathrm{m}^{2} \mathrm{~m}^{-2}\right)$ & 4.76 & 7.43 & 5.20 \\
Stem volume increment $\left(\mathrm{dm}^{3} \mathrm{yr}^{-1}\right)$ & 24.0 & 9.29 & 5.28 \\
\hline
\end{tabular}

* Crown ratio $=$ crown length / tree height (crown length measured by the distance between crown base and stem apex).

established at the beginning and at the end of the growing season as described by Le Goff and Ottorini [26]. One additional tree (9) was used to develop branch volume and biomass equations. Climatic conditions in 1995 were favorable for the growth of ash: temperatures and precipitation during the growing season (May to September) were above the 1960-1999 average (data not presented).

\subsection{Foliage biomass and leaf area}

\subsubsection{Branch level}

For biomass measurements, the leaves of each primary branch of trees 10 and 12 were collected separately, and for tree 6 , only the leaves of the branches that were attainable from the scaffolding were collected. For each tree, detailed leaf-area measurements were obtained from a sub-sample collected on primary branches (one of each age). Leaves were collected at the end of the growing season, in late September, before leaf fall.

The leaves sampled were dried without their petioles in paper bags at $80{ }^{\circ} \mathrm{C}$ for $24 \mathrm{~h}$ before weighing. For the branch sub-samples, the leaves were collected separately for each secondary branch. Before drying, the area (one-sided) of the pinnate leaflets was measured by scanning (Horizon Plus ${ }^{\mathrm{TM}}$, AGFA) the leaves. The NIH Image program (public domain; U.S. National Institutes of Health; http:// rsb.info.nih.gov/nih-image) was used to measure the surface area of the scanned image.

For each tree, the leaf area of the branches that were not sampled was obtained by multiplying the leaf biomass of these branches by the specific leaf area (SLA) of the sub-sample from a branch of the same stem growth unit $[9,14]$.

\subsubsection{Tree level}

The crown of the trees was divided vertically into 3 layers of approximately equal depth (upper, middle and lower) for ecophysiological measurements. For trees 10 and 12, each branch of the tree was attributed to a particular layer of the crown, depending on the position of most of its leaves. The total leaf area of each layer then was calculated by summing the leaf areas of the attributed branches. For tree 6 , the same procedure was applied for the branches for which leaves could be collected. For this tree, the remaining foliage was collected using a net wrapped over the crown [26] from the end of the growth season until all the leaves had fallen, and the contribution $(\%)$ of each crown 
Table II. Foliar biomass, leaf area, mean specific leaf area and leaf area index (LAI) of each crown layer of the three study trees in 1995.

\begin{tabular}{|c|c|c|c|c|c|c|c|c|}
\hline \multirow[t]{2}{*}{ Tree number } & \multirow[t]{2}{*}{ Crown level } & \multicolumn{2}{|c|}{ Foliage biomass } & \multicolumn{2}{|c|}{ Leaf area } & \multirow{2}{*}{$\begin{array}{l}\text { Specific leaf area (SLA) } \\
\qquad \mathrm{cm}^{2} \mathrm{~g}^{-1}\end{array}$} & \multicolumn{2}{|c|}{$L A I$} \\
\hline & & $\mathrm{kg}$ & $\%$ & $\mathrm{~m}^{2}$ & $\%$ & & $\mathrm{~m}^{2} \mathrm{~m}^{-2}$ & $\%$ total \\
\hline & Upper & 1.33 & 23.4 & 11.4 & 20.7 & 86.3 & 1.0 & 20.7 \\
\hline \multirow[t]{4}{*}{6} & Middle & 2.71 & 47.8 & 27.3 & 49.3 & 101 & 2.4 & 49.3 \\
\hline & Lower & 1.63 & 28.8 & 16.6 & 30.0 & 102 & 1.5 & 30.0 \\
\hline & Total & 5.67 & 100 & 55.3 & 100 & 97.6 & 5.0 & 100 \\
\hline & Upper & 0.475 & 21.5 & 6.31 & 15.6 & 133 & 1.1 & 15.6 \\
\hline \multirow[t]{4}{*}{10} & Middle & 0.831 & 37.7 & 13.1 & 32.3 & 158 & 2.3 & 32.4 \\
\hline & Lower & 0.901 & 40.8 & 21.1 & 52.1 & 234 & 3.7 & 52.0 \\
\hline & Total & 2.21 & 100 & 40.5 & 100 & 184 & 7.2 & 100 \\
\hline & Upper & 0.394 & 43.9 & 5.88 & 38.4 & 149 & 2.2 & 38.4 \\
\hline \multirow[t]{3}{*}{12} & Middle & 0.336 & 37.4 & 6.05 & 39.6 & 180 & 2.2 & 39.6 \\
\hline & Lower & 0.169 & 18.7 & 3.36 & 22.0 & 199 & 1.3 & 22.0 \\
\hline & Total & 0.899 & 100 & 15.3 & 100 & 170 & 5.7 & 100 \\
\hline
\end{tabular}

layer to total foliage biomass was calculated for each level using the sampled branches.

The leaf area within each crown level was estimated from the foliar biomass and the mean SLA calculated for that level (Tab. II).

The ratio of petiole to leaflet biomass (0.197) was obtained from a new leaf sample in 1998, and used to estimate the petiole biomass of each study tree.

\subsection{Stem volume increment}

Disks were cut along the stems of the felled trees at $0 \mathrm{~m}$ (butt level), $0.30 \mathrm{~m}, 1.30 \mathrm{~m}, \mathrm{H}_{\mathrm{BC}}$ (crown base), $\mathrm{H}_{\mathrm{MS}}$ (midway between $1.30 \mathrm{~m}$ and $\mathrm{H}_{\mathrm{BC}}$ ), and $\mathrm{H}_{\mathrm{MC}}$ (midway between $\mathrm{H}_{\mathrm{BC}}$ and the end of the stem). On each stem disk, annual radii were measured in four directions at perpendicular angles, starting at the major axis, using a traveling stage microscope with $0.1 \mathrm{~mm}$ precision. The under bark stem volume increment for year 1995 was calculated as the difference between the stem volumes in 1995 and in 1994 obtained from the disk measurements.

\subsection{Branch volume and biomass increments}

\subsubsection{Primary branches}

A single volume equation was developed from measurements obtained before and after the 1996 growing season on a sub-sample of primary branches selected from the different stem growth units of trees $6,10,12$ and 9. To obtain the branch volume for a given year, the diameter of each branch was measured near the base of the branch, at a sufficient distance from branch insertion to avoid butt swell, and at the following relative distances from branch apex: $1 / 4 B, 1 / 2 B$ and $3 / 4 B$, where $B$ is the linear length of the branch. The resulting volume equation for primary branches was the following:

$$
V_{b}=0.35483 D^{2} \cdot B
$$

$$
n=58, \mathrm{MSE}=53.8, P \leq 0.0001, \mathrm{SE}(\text { slope })=0.0033
$$

where $V_{b}$ is the branch volume $\left(\mathrm{cm}^{3}\right)$ and $D$ is the diameter at the base of the branch $(\mathrm{cm})$. As the diameter and length of all the branches on the 3 study trees were not measured for years 1994 and 1995, a set of relations (not shown here) was established to estimate the entries of equation (1), using available branch measurements performed in 1995 and 1996. The volume increment of all the branches inventoried on each tree for year 1995 was then obtained as the difference between the estimated volumes of the branches in 1995 and 1994.

\subsubsection{Secondary branches}

The biomass increments of secondary branches was obtained from masses and cross sectional area increments of the secondary branches that were separated from a sample of primary branches collected from the 3 study trees after they were felled. Three to four main branches were selected per tree at different levels in the crown. For each secondary branch, the following parameters were measured: over bark diameter at the base of the branch, in two perpendicular directions, and dry weight obtained after oven-drying to a constant weight at $105^{\circ} \mathrm{C}$. A sample between 5 and $10 \mathrm{~cm}$ long (increment sample), cylindrical in shape, was taken from the larger secondary branches. The inside bark radius at the base of the increment samples was measured in four perpendicular directions (as for stem disks) for the current year and for the previous one.

Then, the relative biomass increment of each increment sample was calculated as the ratio of the basal area increment to the basal area the cross sectional surface areas being calculated from the geometric means of the four radius measurements taken on each sample. The relative basal area increments of secondary branch increment samples was not depending on the diameter of secondary branches $\left(R^{2}=0.002\right)$ or tree. Their median (0.152, inter-quartile, iq: 0.096-0.251) was used as an estimate of the relative annual biomass increment of the increment samples. The biomass increment of each secondary branch was then calculated as 0.152 times its biomass.

To calculate the total biomass increment of the secondary branches of each tree, the following relation was established by nonlinear regression (DataDesk, Version 6, Data Description Inc., Ithaca, NY, USA):

$$
\begin{gathered}
\Delta B_{S}=11.8618 \cdot \ln \left(1+\exp ^{3.7329(D-1.831)}\right) \\
n=13, \mathrm{MSE}=5.21
\end{gathered}
$$


Table III. Mean wood densities $\left(\mathrm{g} \mathrm{cm}^{-3}\right) \pm \mathrm{SE}$ obtained from stem and branch samples.

\begin{tabular}{lcc}
\hline Tree & Stem & Branches \\
\hline 6 & $0.606 \pm 0.038$ & $0.628 \pm 0.017$ \\
10 & $0.593 \pm 0.028$ & $0.604 \pm 0.022$ \\
12 & $0.551 \pm 0.026$ & $0.586 \pm 0.014$ \\
\hline
\end{tabular}

where $D$ is the basal diameter of a primary branch $(\mathrm{cm})$, and $\Delta B_{s}$ is the total biomass increment of its secondary branches $(\mathrm{g})$.

\subsection{Wood density (stem and branches)}

Wood samples were taken on the three study trees after they were felled to obtain "green specific gravity" values for use in converting volume increments to dry weight increments for the stem and the primary branches. Five disks were cut from the stem, at the heights where the increment measurements were made. Disks were also taken from six branches selected from the three crown levels. The dry weight and the volume of each sample were measured and the green specific gravity of the samples was obtained (ratio of dry weight to volume). No clear dependence was found between the wood density of the stem or branch samples and their locations in the tree (distance from stem apex). Then, the mean wood densities of the stem and branches of each tree were calculated from the green specific gravity of the corresponding tissue samples (Tab. III) to obtain biomass increments from volume increments.

\subsection{Root biomass increment}

The root systems of the 3 study trees were excavated after tree felling in autumn 1998 using an excavator to minimize loss or breakage of roots. For roots broken during excavation, where possible, the part remaining in the soil was excavated to allow reconstruction of the broken roots. After being excavated, the roots were washed to remove soil particles and exposed to the open air to dry.

Biomass was measured after roots were sorted into three size classes and then oven-dried to a constant weight at $105^{\circ} \mathrm{C}$ : coarse roots $(d \geq 5 \mathrm{~mm})$, small roots $(2 \geq d<5 \mathrm{~mm})$ and fine roots $(d<2 \mathrm{~mm})$. In a similar way as described by Le Goff and Ottorini [27], the biomass of missing root ends of each tree was estimated to obtain annual biomass increments of the root systems. This was done, in addition, accounting, where possible, for the morphological type of roots (tape, horizontal). Following this procedure, samples of regular shape from coarse and small roots were cut and their volumes in $1998\left(V_{98}\right)$ and annual volume increments in $1995\left(d V_{95}\right)$ were obtained (in the same way as for branch increment samples).

As the relative volume increments of the increment samples (ratio of the volume increment $\left(d V_{95}\right)$ to the volume of the samples $\left.\left(V_{98}\right)\right)$ was independent of the cross-sectional area $\left(R^{2}=0.02\right)$, the median $(k)$ of the relative volume increments for each tree was used as an estimate of the relative volume increment of the whole root system for 1995 . Specifically, $k$ was 0.079 for tree 6 (iq: $0.052-0.118$ ), 0.0455 for tree 10 (iq: $0.035-0.143$ ), and 0.025 for tree 12 (iq: $0.0185-0.058$ ). These medians were statistically different when compared with the MannWhitney $U$ test. Assuming wood density is constant among all parts of each root system and between years 1995 and 1998, the relative biomass increment $\left(d B_{95} / B_{98}\right)$ is equal to the relative volume increment $\left(d V_{95} / V_{98}\right)$. Then, the biomass increment of the root systems of the 3 sampled trees was calculated as the product of tree root biomass (coarse and small roots) in $1998\left(B_{98}\right)$ and the relative root biomass increment $\left(d B_{95} / B_{98}\right)$ characteristic of each tree.

\subsection{Carbon conversion}

Few data exist for ash to convert wood biomass to carbon content, and they do not seem very reliable; moreover, a comparison between species shows that the range of variation of carbon content is small [32]. Then, biomass data for the different tree compartments were converted into $C$ mass using the equivalent: $1 \mathrm{~kg}$ dry matter equals $0.45 \mathrm{~kg} \mathrm{C}$. This conversion is from data obtained recently for beech (Fagus sylvatica L.) showing that the carbon contents of the different tree compartments are similar, ranging between $44 \%$ and $45.7 \%$ [39].

\subsection{Microclimate and ecophysiology of trees}

Carbon balance was estimated over a period of approximately one year, extending between the end of leaf fall in 1994 and the end of leaf fall in 1995. For trees 10 and 12, these dates corresponded to the dates of leaf collection by hand, that is, days of the year (DOY) 263 and 262 in 1994 and 1995 respectively; for tree 6, leaves could be collected by hand only partially, and then, remaining leaves had to be collected in a net enclosing the crown as and when they were naturally falling until the end of leaf fall (DOY 306 and 296 in 1994 and 1995 respectively).

\subsubsection{Microclimate}

The following meteorological observations were made in 1995 above the tree canopy, at a height of $17 \mathrm{~m}$ (top of the scaffoldings) and for a period extending from DOY 118 to 250: wind speed, using a switching anemometer (Vector Instruments, UK); rainfall, using a rain gauge (ARG 100, Campbell Scientific, Logan, USA); global radiation, using a solar radiometer (Model CE-180, Cimel, Paris); and, air humidity and temperature, using a ventilated psychrometer (equipped with Pt 100 probes). A second psychrometer was installed at a height of $10.5 \mathrm{~m}$ to detect gradient in the tree canopy. Also, linear radiometers, $33 \mathrm{~cm}$ in length (INRA, Versailles, France), were installed in the middle of each of the three crown layers of the three study trees. Each radiometer was fixed at the end of a horizontal arm to measure the mean global radiation in each crown layer. Data were acquired every $10 \mathrm{~s}$, and 30-min averages were stored (Model CR7 data logger, Campbell Scientific, Courtabœuf, France).

Global radiation above the tree canopy compared favorably with that of a weather station (Amance) close to the forest, allowing using the data from this station for the periods without measurements at tree level (i.e. from the end of leaf fall in 1994 until DOY 118 in 1995 and from DOY 250 to DOY 296 in 1995). Moreover, for these periods, the global radiation in each crown layer of the three trees was estimated from light transmittance values obtained for the period of radiation measurement in trees and from global radiation values of the nearby weather station [28]. As a consequence, total leaf expansion in 1995 could be considered to be complete when transmitted radiation ceased to decrease (DOY 156,159 and 165 for trees 6,10 and 12 respectively).

\subsubsection{Net assimilation}

Net $\mathrm{CO}_{2}$ assimilation rate $\left(A_{n}\right)$ of leaves was measured in situ weekly at $12 \mathrm{H}$ GMT throughout the growing season, using a portable system (LI-6200, Li-Cor Inc., Lincoln, NE, USA); in addition, a diurnal course of $\mathrm{CO}_{2}$ exchange was performed on one day (DOY 200) at the rate of one measurement per hour, from 7H GMT to 19H GMT. Six measurements were taken on each tree, two per crown layer in different directions. These measurements were made under ambient light on groups of 3 to 7 leaflets selected randomly at the beginning of the growing season from branches close to the linear radiometers installed in each crown layer. The same groups of leaflets were used throughout the growing season and the area of these leaflets was measured for calculations of net assimilation per unit of leaf area. 
Table IV. Annual biomass and carbon increments of the different compartments of the study trees in 1995. The foliar compartment includes petioles.

\begin{tabular}{|c|c|c|c|c|c|c|c|c|c|c|}
\hline \multirow[b]{2}{*}{ Tree } & \multicolumn{2}{|c|}{ Foliage } & \multicolumn{2}{|c|}{ Stem } & \multicolumn{2}{|c|}{ Branches } & \multicolumn{2}{|c|}{ Roots } & \multicolumn{2}{|c|}{ Stem + Branches + Roots } \\
\hline & $\begin{array}{l}\text { Dry matter } \\
(\mathrm{kg})\end{array}$ & $\begin{array}{c}\mathrm{C} \\
(\mathrm{kg})\end{array}$ & $\begin{array}{c}\text { Dry matter } \\
(\mathrm{kg})\end{array}$ & $\begin{array}{c}\mathrm{C} \\
(\mathrm{kg})\end{array}$ & $\begin{array}{c}\text { Dry matter } \\
(\mathrm{kg})\end{array}$ & $\begin{array}{c}\mathrm{C} \\
(\mathrm{kg})\end{array}$ & $\begin{array}{l}\text { Dry matter } \\
(\mathrm{kg})\end{array}$ & $\begin{array}{c}\mathrm{C} \\
(\mathrm{kg})\end{array}$ & $\begin{array}{l}\text { Dry matter } \\
(\mathrm{kg})\end{array}$ & $\begin{array}{c}\mathrm{C} \\
(\mathrm{kg})\end{array}$ \\
\hline 6 & 6.79 & 3.06 & 17.16 & 7.22 & 8.65 & 3.89 & 5.56 & 2.50 & 31.37 & 14.12 \\
\hline 10 & 2.64 & 1.19 & 4.93 & 2.22 & 2.48 & 1.12 & 1.32 & 0.59 & 8.73 & 3.93 \\
\hline 12 & 1.08 & 0.49 & 3.25 & 1.46 & 0.80 & 0.36 & 0.29 & 0.13 & 4.34 & 1.95 \\
\hline
\end{tabular}

Scaling of net $\mathrm{C}$ assimilation to the tree level was done as follows: (i) response curves were established between net $\mathrm{C}$ assimilation $\left(A_{n}\right.$, $\left.\mu \mathrm{mol} \mathrm{CO}_{2} \mathrm{~m}^{-2} \mathrm{~s}^{-1}\right)$, and measured global radiation $\left(R_{g}, \mathrm{~W} \mathrm{~m} \mathrm{~m}^{-2}\right)$, for each crown layer of the sample trees; (ii) instantaneous net assimilation was calculated for each crown layer using continuous global radiation measurements (30-min averages) and the response curves for $A_{n}$ and $R_{g}$; (iii) net assimilation per crown layer was calculated by multiplying instantaneous net assimilation values and the leaf area of the corresponding crown layer; and finally, (iv) total net $\mathrm{C}$ assimilation per tree was obtained by summing the net $\mathrm{C}$ assimilation values of the three crown layers.

\subsubsection{Carbon balance}

To calculate net carbon uptake by trees $\left(C_{B}\right)$, it is necessary to take into account the respiration of the different tree compartments [23]. Assuming (Assumption 1) that leaf respiration during the night is equal to leaf respiration during daylight, then for any time of day:

$$
C_{B}=A_{G}+R_{f}+R_{w}+R_{r}
$$

where $A_{G}$ is the gross $\mathrm{C}$ assimilation by the tree, $R_{f}$ is the foliar respiration, $R_{w}$ is the respiration of the woody tissues (stem and branches), and $R_{r}$ is the respiration of roots. The following sign conventions are used: negative for assimilation and positive for respiration.

For the growing season, during daylight, net $\mathrm{C}$ assimilation $\left(A_{N}\right)$ is related to gross $\mathrm{C}$ assimilation $\left(A_{G}\right)$ by the following equation:

$$
A_{N}=A_{G}+R_{f}
$$

and then, equation (3) can be re-written as:

$$
C_{B}=A_{N}+R_{w}+R_{r} .
$$

For the growing season, during the night, and for the dormant season, $A_{G}=0$, and then, equation (3) becomes in this case:

$$
C_{B}=R_{f}+R_{w}+R_{r} .
$$

Defining $R_{A}$ as the aboveground respiration $\left(R_{A}=R_{f}+R_{w}\right), R_{s r}$ as the soil + roots respiration and $R_{E}$ as the ecosystem respiration, scaled at tree level, $\left(R_{E}=R_{A}+R_{s r}\right)$, we obtain:

$$
R_{f}+R_{w}=R_{A}=R_{E}-R_{s r} .
$$

For the daylight period of the growing season, we can assume moreover (Assumption 2) that $R_{w}=R_{f}$, which gives:

$$
R_{f}=R_{w}=\frac{1}{2} R_{A} \quad \text { or: } \quad R_{f}=R_{w}=\frac{1}{2}\left(R_{E}-R_{s r}\right) .
$$

Then, equations (4) and (5) become respectively:

$$
C_{B}=A_{N}+\frac{1}{2}\left(R_{E}-R_{s r}\right)+R_{r}
$$

and,

$$
C_{B}=\left(R_{E}-R_{s r}\right)+R_{r} .
$$

If we consider now that respiration from roots $\left(R_{r}\right)$ represents $60 \%$ of the $\mathrm{CO}_{2}$ flux from the soil $\left(R_{s r}\right)$, as observed by Epron et al. [10] in a beech stand of the same age, root respiration $\left(R_{r}\right)$ in equations (6) and (7) can be calculated as:

$$
R_{r}=0.6 R_{s r} .
$$

In the absence of direct measurements, ecosystem respiration $\left(R_{E}\right.$, $\left.\mu \mathrm{mol} \mathrm{CO} \mathrm{Cm}^{-2} \mathrm{~s}^{-1}\right)$ and belowground respiration $\left(R_{s r}, \mu \mathrm{mol} \mathrm{CO} \mathrm{Cm}^{-2} \mathrm{~s}^{-1}\right)$ were estimated from equations obtained by Granier et al. [15] for $R_{E}$ and by Epron et al. [10] for $R_{s r}$ :

$$
\begin{gathered}
R_{E}=0.531 \times 10^{0.057 t_{\text {sooi }}} \\
R_{s r}=0.436 \times 10^{0.0509_{\text {soil }}} .
\end{gathered}
$$

Unmeasured soil temperature, $t_{\text {soil }}\left(\right.$ in $\left.{ }^{\circ} \mathrm{C}\right)$, was related to air temperature, $t_{\text {air }}\left(\right.$ in $\left.^{\circ} \mathrm{C}\right)$, by the following equation:

$$
t_{\text {soil }}=6.818+0.450 t_{\text {air }} \text {. }
$$

Net carbon uptake by trees $\left(C_{B}\right)$ was calculated for each 30-min period from equations (6) or (7) depending on the period of the year, using response curves for $A_{n}$ versus $R_{g}$ (described above), and by scaling the ecosystem respiration rates obtained from equations (8) and (9) to the tree level. This scaling operation was done by multiplying the respiration rates (in $\mu$ mol $\mathrm{CO}_{2} \mathrm{~m}^{-2} \mathrm{~s}^{-1}$ ) by the crown projection area of the trees. During the growing season, it was considered that it was the night when net assimilation $\left(A_{n}\right)$ calculated from global radiation $\left(R_{g}\right)$ became less than 0 . In the present study, $A_{N}$ was calculated per crown layer and the assumption above was applied separately to each crown layer.

\section{RESULTS}

\subsection{Biomass increment}

\subsubsection{Carbon uptake}

The biomass increment for the woody compartments (stem, branches and roots) of the 3 trees was obtained for year 1995 and converted to carbon mass (Tab. IV). The foliage production was obtained by adding the biomass of the petioles to that of the leaflets. The total dry matter production reached $38.2 \mathrm{~kg}$ year -1 for tree $6,11.4 \mathrm{~kg}_{\text {year }}-1$ for tree 10 , and $5.4 \mathrm{~kg} \mathrm{year}^{-1}$ for tree 12 , which represented an annual net carbon uptake of $2.4,5.1$ and $17.2 \mathrm{~kg}$ for trees 12,10 and 6 respectively.

\subsubsection{Partitioning}

The largest part of the biomass increment went to the stem; the next largest part went to the foliage and branches (Fig. 1). The contribution of coarse and small roots to the biomass increment is smaller (less than 15\%). However, differences existed 


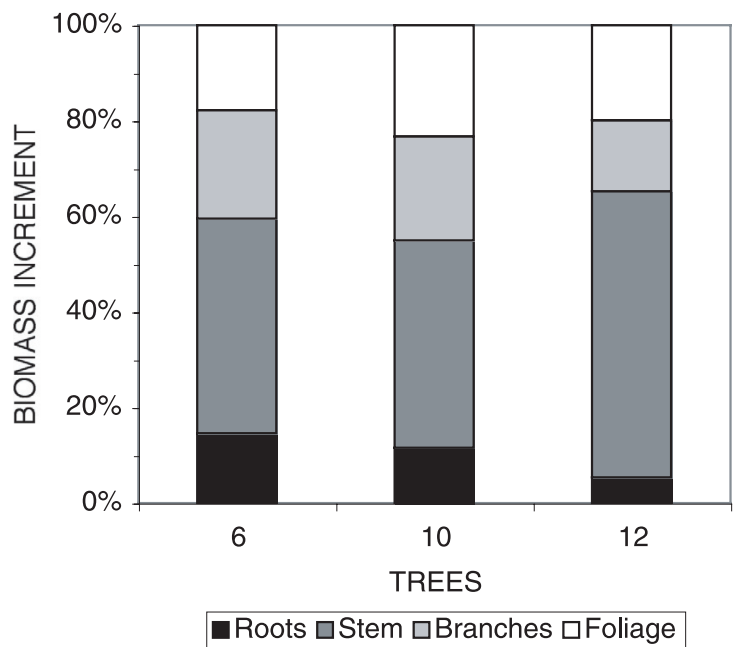

Figure 1. Relative contribution of the different tree compartments to the 1995 biomass increment of the three study trees.

between the three study trees. The proportion of the biomass increment allocated to the stem, branches and roots was about the same for trees 6 and 10 (approximately 45\%,22\% and 13\%, respectively), whereas the biomass increment allocated to the stem of tree 12 was $60 \%$ compared to $15 \%$ to branches and only $5 \%$ to the root system.

\subsubsection{Biomass increment in relation to leaf area}

The total biomass increment (wood biomass increment, $I_{w}$ ) increased sharply with total leaf area $(L A)$ within the range of the observed values (Fig. 2a). Moreover, the biomass increment per unit of foliage area $\left(I_{w} / L A\right)$ appeared linearly related, in natural log scale, to the leaf area index (LAI) (Fig. 2b). The following relation was established:

$$
\begin{aligned}
\ln \left(\frac{I_{w}}{L A}\right) & =1.5368-1.4074 \cdot \ln (L A I) \\
n & =3, R^{2}=0.98, \mathrm{MSE}=0.1062 .
\end{aligned}
$$

After inverse transformation of equation (11) and correction for bias [13], we obtained:

$$
I_{w}=4.6760 \frac{L A}{L A I^{1.4074}} .
$$

\subsection{Net carbon uptake from simulated $\mathrm{CO}_{2}$ fluxes}

\subsubsection{Net assimilation in relation to global radiation}

First, net assimilation $\left(A_{n}\right)$ was related to global radiation $\left(R_{g}\right)$ for each crown layer of the three study trees, using the following model [42]:

$$
A_{n}=\frac{a R_{g}}{R_{g}+b} .
$$

Examination of the scattergrams of $A_{n}$ versus $R_{g}$ with the fitted curves obtained from equation (13) indicated that a common response curve for the 3 trees could be established for each crown layer. Moreover, if net assimilation for a given $R_{g}$ was
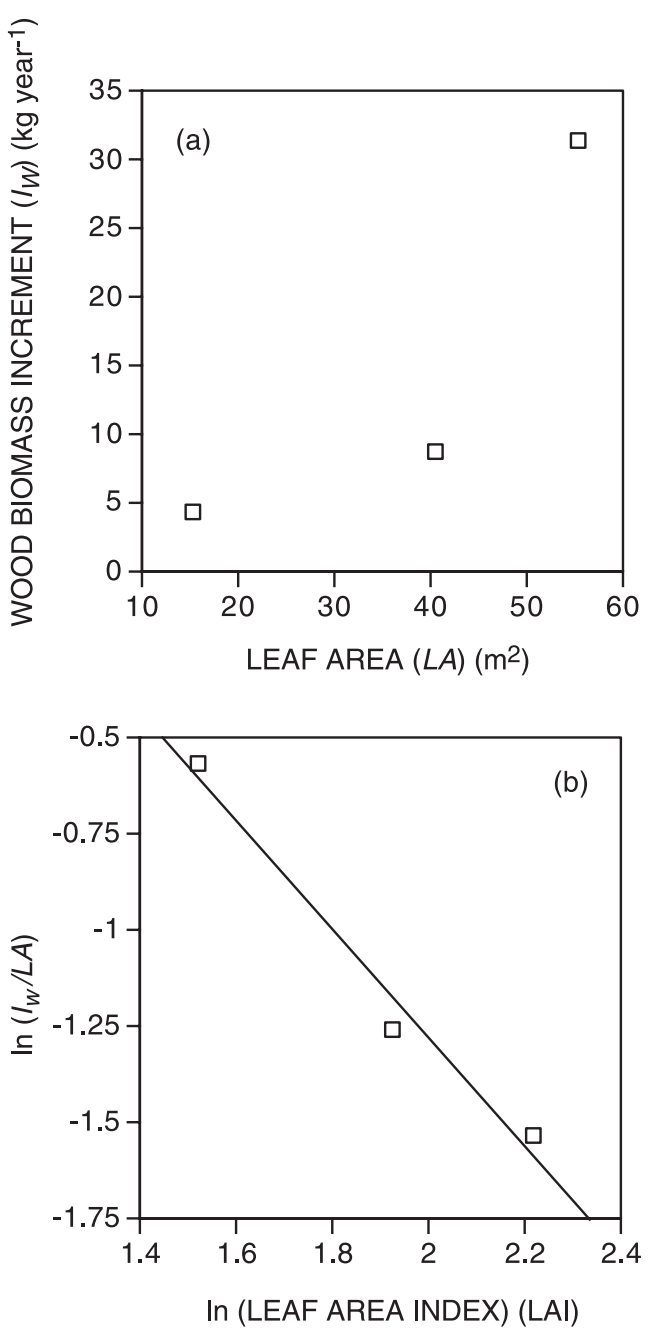

Figure 2. (a) Observed wood biomass increment $\left(I_{w}\right)$ versus total leaf area (one data point for each of 3 study trees); (b) wood biomass increment per unit of foliage area $\left(I_{w} / L A\right)$ in relation to leaf area index $(L A I)$

set equal to 1 for the lower crown layer, then $A_{n}$ would be approximately equal to 2 and 3 for the middle and the upper layers, respectively. In addition, potential evapotranspiration (PET) appeared to interact with global radiation.

Next, equation (13) was modified to obtain the following model that was fitted to the data (R Development Core Team 2003, http://www.R-project.org):

$$
A_{n}=k_{i} \frac{R_{g}(a+c P E T)}{R_{g}+b}
$$

where $k_{i}=1$ for the lower crown layer, 2 for the middle, and 3 for the upper. Units for $A_{n}$ are $\mu \mathrm{mol} \mathrm{CO}_{2} \mathrm{~m}^{-2} \mathrm{~s}^{-1}$, for $R_{g}, \mathrm{~W} \mathrm{~m} \mathrm{~m}^{-2}$, and for $P E T, \mathrm{~mm} \mathrm{~h}^{-1}$. The other microclimatic variables available (i.e., temperature and water vapor deficit) were not useful for further reduction of the residual mean square error of the model. The estimated values and associated statistics of the parameters $a, b$ and $c$ are listed in Table $\mathrm{V}$. 
Table V. Regression coefficients and statistics for equation (13) relating net assimilation $\left(A_{n}\right)$ to global radiation $\left(R_{g}\right)$ and potential evapotranspiration (PET) (SE: standard error of the estimator).

\begin{tabular}{lccc}
\hline Parameter & Estimation & SE & $P$ \\
\hline $\mathrm{a}$ & 3.0005 & 0.7480 & 0.0001 \\
$\mathrm{~b}$ & 81.0387 & 23.0573 & 0.0006 \\
$\mathrm{c}$ & 4.3220 & 1.0090 & $<0.0001$ \\
\hline
\end{tabular}

The observed variation in net assimilation versus global radiation for each crown layer of the three study trees is shown in Figure 3, together with the predicted values obtained from equation (14). A response curve, calculated with PET set to the mean of the observed values, is also represented. The predicted values, together with the curve, were used to evaluate the amount of unexplained variation in $A_{n}$ resulting from the effects of PET. Generally, the predicted values are closer to the observed values than the curve is (Fig. 3); therefore, PET and $R_{g}$ explain more of the variation in $A_{n}$ than radiation alone.

\subsubsection{Carbon fluxes at the tree level}

The minimum values of light transmittance $\left(\tau_{\min }\right)$ and the day of year $\left(\mathrm{DOY}_{\mathrm{cld}}\right)$ when this minimum was reached after complete leaf development for each crown layer of the three study trees, are given in Table VI (see [28] for details). The minimum light transmittance values were used to estimate the global radiation at each crown level for the periods with missing data.

Net assimilation $\left(A_{N}\right)$ for each tree was then calculated according to equation (14), using either the microclimatic data ( $R g$ and $P E T$ ) registered each $30 \mathrm{~min}$ throughout the growing season (from bud burst ${ }^{1}$ to DOY 250 ) or those from the nearby weather station (from DOY 250 to DOY 296) and the leaf areas calculated for each crown layer (see Tab. II). For the period of leaf development (from bud burst to DOY ${ }_{\text {cld }}$ ), leaf area was considered to increase linearly. Similarly, for tree 6 for which all the leaves were not collected by hand at the end of the growing season, leaf area was considered to decrease linearly for the period of leaf fall in 1995.

Values for crown projection area (see Tab. I) were used to scale ecosystem and belowground respiration (Eqs. (8) and (9)) to the tree level. Carbon balance of trees $\left(\mathrm{C}_{B}\right)$ was calculated from net assimilation $\left(A_{N}\right)$ and from respiration estimates $\left(R_{E}\right.$ and $R_{s r}$ ) using equations (6) and (7) during daylight and night respectively. Gross assimilation during day light $\left(A_{G}=A_{N}+R_{f}\right)$ was also obtained from $A_{N}, R_{E}$ and $R_{s r}$, using the relation linking $\mathrm{R}_{f}$ to $R_{E}$ and $R_{s r}$ :

$$
A_{G}=A_{N}-\frac{1}{2}\left(R_{E}-R_{s r}\right) .
$$

The results obtained from the calculations above are presented in Table VII.

Carbon fluxes increased with tree size: the carbon uptake $\left(C_{B}\right)$ of tree 6 was about four times greater than that of tree 12 and about two times greater than that of tree 10. Total respiration of trees $\left(R_{A}+R_{r}\right)$ represented about $37 \%$ of the gross assimilation $\left(A_{G}\right)$ of trees (Fig. 4).

\subsubsection{Net primary productivity from $\mathrm{CO}_{2}$ fluxes and tree growth}

Carbon balance $\left(C_{B}\right)$ was compared to total biomass increment in 1995 for the three sample trees (Fig. 5). Biomass increment amounted to $125 \%, 70 \%$ and $67 \%$ of the carbon balance for trees 6, 10 and 12, respectively. In addition, biomass increment appeared lower than expected from carbon flux measurements for trees 10 and 12, whereas it was greater for tree 6.

\section{DISCUSSION}

\subsection{Biomass increment}

Biomass increment was estimated carefully for each tree compartment (foliage, stem, branches and roots). Only fine root production by the sample trees could not be estimated, but it should represent only a small fraction of biomass increment. For beech trees of the same age, yearly fine root production represented about $35 \%$ of total root biomass increment [27] that is about $5.5 \%$ of total tree biomass increment.

The biomass increment of tree 6 with the largest crown (and superior competitive status) was 7 times greater than that of tree 12 with the smallest crown. Generally, a larger crown supports a larger leaf area. Wood biomass increment appeared to be proportional to leaf area and inversely proportional to LAI raised to the power 1.4 (Eq. (12)). This result agrees with those obtained previously on a larger sample of ash trees in a related experiment [26]. In that study, bole volume increment was related to foliage biomass and to a measure of foliar density that was related linearly to $L A I$. The decrease in foliar efficiency (defined here as dry matter produced per unit of leaf area) with increasing leaf area index has been observed previously at tree and stand levels [35, 41, 43-45]. This phenomenon may be

Table VI. Day of year when complete leaf development (cld) is reached (DOY cld $_{\text {) }}$ and corresponding minimum light transmittance values $\left(\tau_{\min }\right)$ for each crown layer of the study trees in 1995.

\begin{tabular}{|c|c|c|c|c|c|c|}
\hline \multirow{2}{*}{ Crown layer } & \multicolumn{2}{|c|}{ Tree 6} & \multicolumn{2}{|c|}{ Tree 10} & \multicolumn{2}{|c|}{ Tree 12} \\
\hline & $\mathrm{DOY}_{\text {cld }}$ & $\tau_{\min }$ & DOY $_{\text {cld }}$ & $\tau_{\min }$ & $\mathrm{DOY}_{\mathrm{cld}}$ & $\tau_{\min }$ \\
\hline Upper & 145 & 0.46 & 152 & 0.33 & 165 & 0.38 \\
\hline Middle & 156 & 0.46 & 141 & 0.42 & 165 & 0.34 \\
\hline Lower & 146 & 0.30 & 159 & 0.23 & 162 & 0.30 \\
\hline
\end{tabular}

\footnotetext{
${ }^{1}$ The dates of bud burst in 1995 for the study trees were the following: DOY 118, 122 and 129 for trees 6, 10 and 12 respectively.
} 
Tree 6
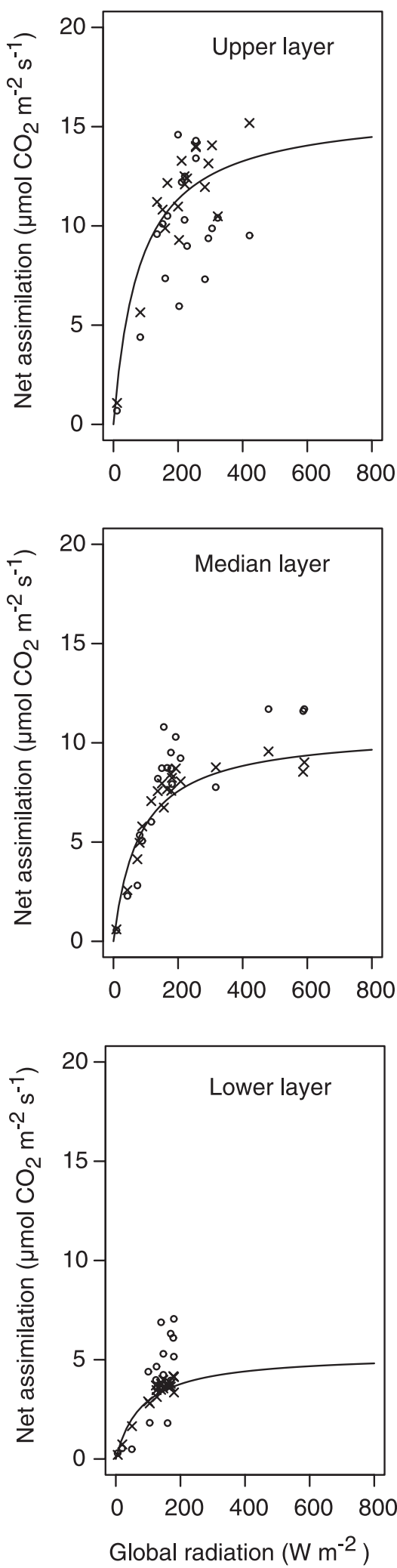

Tree 10
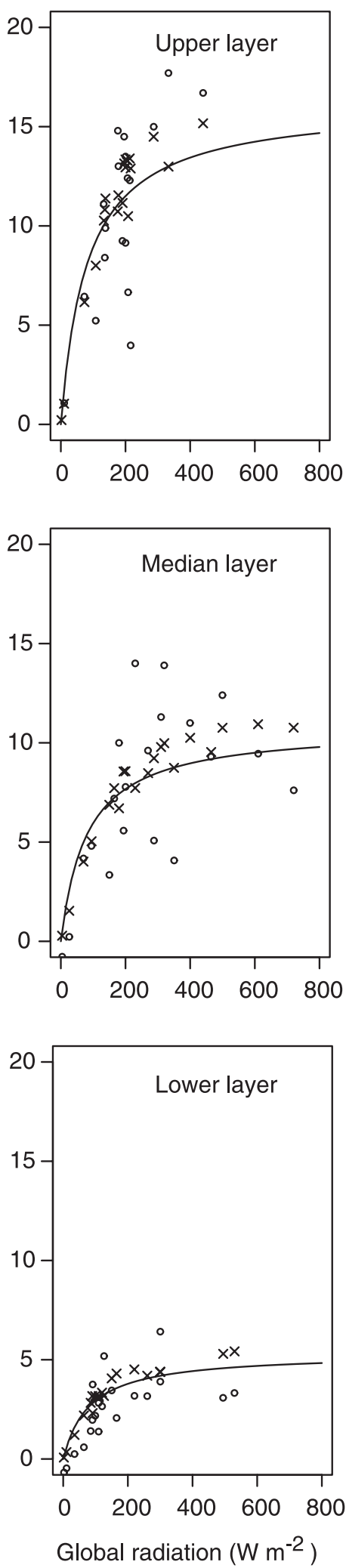

Tree 12
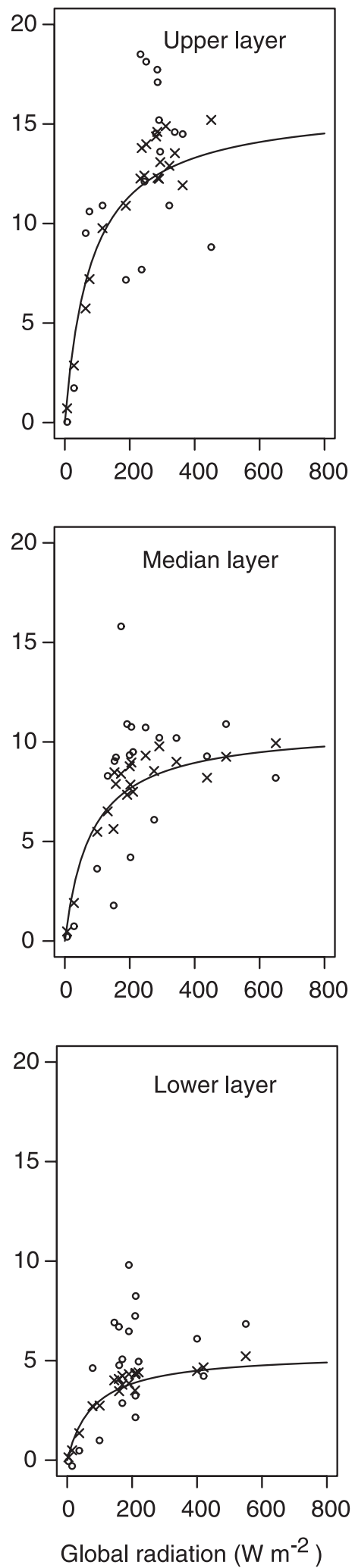

Figure 3. Net assimilation $\left(A_{n}\right)$ for the three crown layers of each sample tree in relation to global radiation $\left(R_{g}\right)$ : fitted curves are presented for $P E T$ fixed to the mean of the observed values (o). The fitted values (x) obtained from equation (14) are also represented. 
Table VII. Yearly carbon fluxes at tree level (in kg C): $A_{N}$, net assimilation; $R_{E}$, ecosystem respiration; $R_{s}$, soil + roots respiration; $A_{G}$, gross assimilation; and $\mathrm{C}_{B}$, carbon balance. Fluxes were calculated from the end of leaf fall (or date of leaf collection) in 1994 until the end of leaf fall (or date of leaf collection) in 1995.

\begin{tabular}{lrrrrr}
\hline Tree & $A_{N}$ & $R_{E}$ & $R_{s r}$ & $A_{G}$ & $\mathrm{C}_{B}$ \\
\hline 6 & -20.59 & 11.05 & 7.58 & -21.75 & -13.73 \\
10 & -11.01 & 5.86 & 4.02 & -11.58 & -7.33 \\
12 & -5.43 & 2.84 & 1.95 & -5.70 & -3.64 \\
\hline
\end{tabular}

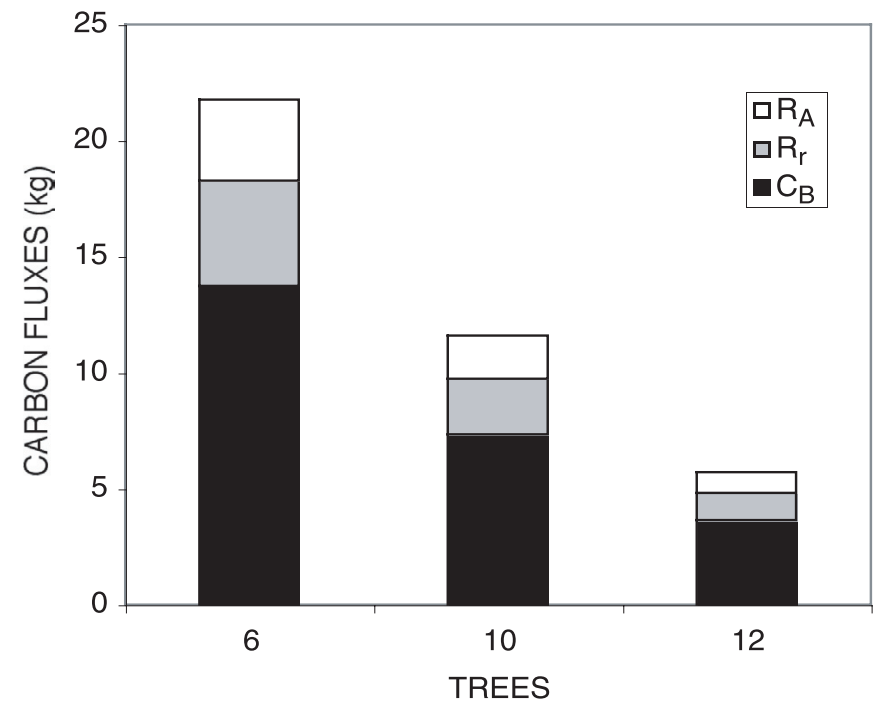

Figure 4. Carbon fluxes for the three study trees during a one-year cycle (from the end of leaf fall in 1994 to the end of leaf fall in 1995). The total of carbon balance $\left(\mathrm{C}_{B}\right)$, root respiration $\left(R_{r}\right)$ and aboveground respiration $\left(R_{A}\right)$ equals gross carbon assimilation $\left(A_{G}\right)$.

related to the lower assimilation rate of shaded leaves that contribute more to total leaf area as $L A I$ increases (see Tab. II). The lower efficiency of tree $10\left(0.2 \mathrm{~kg} \mathrm{~m}^{-2} \mathrm{yr}^{-1}\right)$ compared to that of trees $6\left(0.6 \mathrm{~kg} \mathrm{~m}^{-2} \mathrm{yr}^{-1}\right)$ and $12\left(0.3 \mathrm{~kg} \mathrm{~m}^{-2} \mathrm{yr}^{-1}\right)$ may thus be explained.

Stems contributed more than $45 \%$ of the carbon allocation in the trees during the growing season, whereas the other compartments (leaves, branches and roots) each contributed less than $25 \%$. The stem appeared to be the major carbon sink at this age, as has been observed for other broad-leaved species [24] or conifers [1]. Carbon allocation to the stem can reach even higher levels in highly crowded trees, to the detriment of roots and branches $[4,5]$.

\subsection{Carbon fluxes}

\subsubsection{Net assimilation}

To account for the spatial variation of global radiation and of net assimilation in the canopy, the crown of each tree was divided into 3 horizontal layers. A sample of leaves was chosen at each level of the crown for photosynthesis measurements and integrated radiation was measured near the sampled leaves continuously during the growing season. The inclination of branches

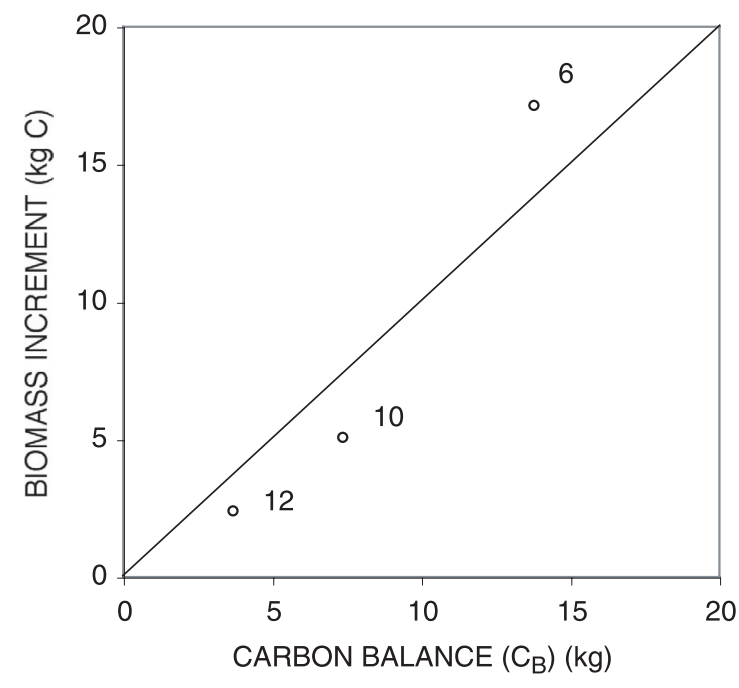

Figure 5. Biomass increment (leaves + wood) of the three study trees in 1995 in relation to the carbon balance $\left(\mathrm{C}_{B}\right)$ obtained from $\mathrm{CO}_{2}$ flux measurements (see Fig. 4). The 1:1 line is represented.

sometimes made it difficult to allocate the foliage of a given branch to one crown layer. Moreover, differences in global radiation and assimilation rate could occur because of the position of leaves along the branch: leaves located toward the interior of the crown are likely to be more shaded than those at the periphery. However, it would have been difficult to sample more leaves for photosynthesis measurements. As it was, the sample represented between 0.1 and $0.3 \%$ of the total foliage of the study trees, and it was possible to install only one radiometer per crown layer.

The response of net assimilation to global radiation was consistent with other results reported in the literature [12]. The photosynthetic capacity of ash seems higher than that of other broad-leaved trees. Considering leaves in the upper crown layer, maximum net assimilation $\left(A_{n} \max \right)$ averaged $12.5 \mu \mathrm{mol} \mathrm{m}{ }^{-2} \mathrm{~s}^{-1}$ for the ash in the present study, but only $10 \mu \mathrm{mol} \mathrm{m}^{-2} \mathrm{~s}^{-1}$ for beech (Fagus sylvatica) in similar climatic conditions [24]. At a more Atlantic site in the southern UK, $A_{n} \max$ was only 3.5 and $10.4 \mu \mathrm{mol} \mathrm{m}^{-2} \mathrm{~s}^{-1}$ for sun leaves of sycamore (Acer pseudoplatanus) and oak (Quercus robur) respectively [33].

The decrease in net assimilation from the upper to the lower crown layers can be explained by the general decrease in the level of global radiation and also by the decrease in nitrogen concentration in leaves from the top to the bottom of the crown 


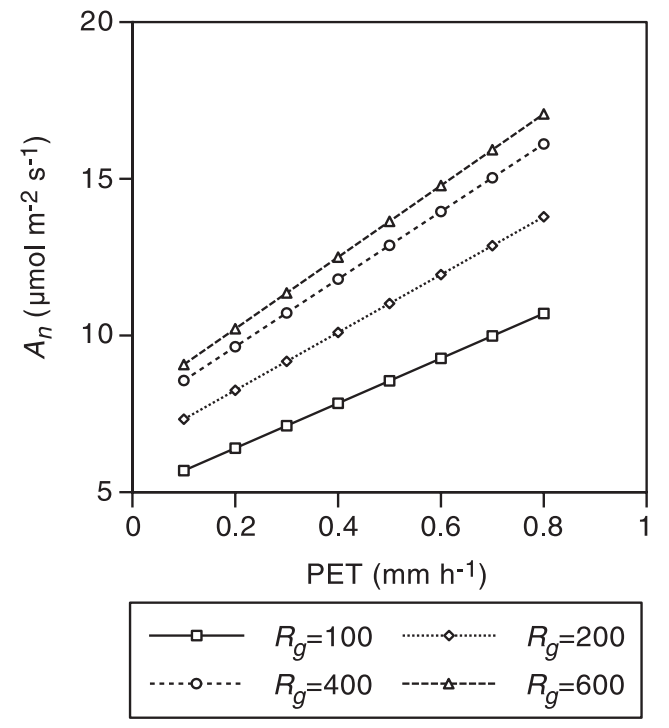

Figure 6. Net assimilation $\left(A_{n}\right)$ in relation to potential evapotranspiration $(P E T)$ for different levels of global radiation $\left(R_{g}\right.$ in $\left.\mathrm{W} \mathrm{m}^{-2}\right)$, from equation (13).

$[29,38]$. The increase in specific leaf area from the upper to the lower crown levels of our ash trees may indicate a decrease in nitrogen, as observed for sycamore [33].

Environmental factors other than $R g$ could influence net assimilation during the growing season. These factors include temperature, water availability, or vapor pressure deficit (VPD) $[22,37]$. During 1995, water was not a limiting factor for ash in our experiment (data not presented). We found a positive correlation between net assimilation of sample trees and potential evapotranspiration (PET) (Fig. 6), however no clear dependence with temperature and VPD was detected. Thus, temperature and air humidity did not seem to have a limiting effect on assimilation rate in this case, indicating that the thresholds beyond which assimilation would decrease were not reached [17] and that the sample trees experienced optimal growing conditions in 1995, in terms of water availability, air humidity and temperature.

For a given crown layer, net assimilation appeared to be independent of tree competitive status (crown ratio). Although the three trees were growing in different local environments, their crowns received about the same quantity of light. Thus, for a given crown level, radiation levels were relatively similar, at least at the periphery of the crown.

Seasonal trends of net assimilation are not discussed here. For the purpose of this study, the variations in net assimilation during the growing season were estimated, based on relationships established between $A_{n}, R_{g}$ and PET, and on meteorological data recorded continuously throughout the growing season.

\subsubsection{Respiration}

Respiration data were not available, and we assumed that the respiration of the study trees could be estimated from relations established at the stand level for an experimental beech stand of similar age growing in similar climatic and soil conditions.

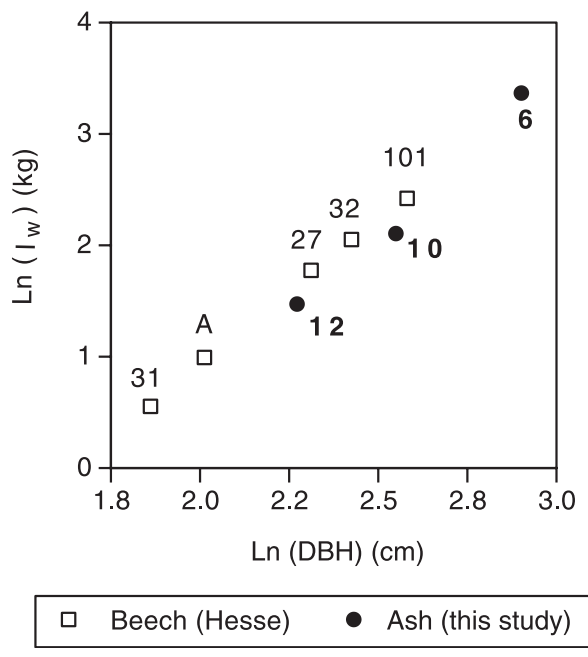

Figure 7. Annual wood biomass increment $\left(I_{w}\right)$ of the study trees (ash) in relation to tree diameter at breast height (DBH), compared to wood biomass increment of beech trees of comparable diameter in an experimental stand (Hesse) in northeastern France [24].

For comparable diameters, the biomass increment of beech trees sampled in this experimental stand [24] was close to that observed for the study (ash) trees (Fig. 7). Moreover, data from the literature show that the respiration of ash and beech stands of comparable age in Denmark - where the climate is not very different from the climate in the northeast of France - was similar, amounting to 8.0 and $8.8 \mathrm{tDM} \mathrm{ha}^{-1} \mathrm{y}^{-1}$, respectively [40].

Several of the assumptions made to estimate the respiration of trees, for example, that respiration is dependent only on temperature and is independent of time of day (Assumption 1), and that respiration of woody tissue equals leaf respiration $\left(R_{w}\right.$ equals half of $R_{A}$, Assumption 2) have been discussed elsewhere $[15,24]$. However, respiration of trees may depend on other environmental factors such as soil water content that can determine partly soil $\mathrm{CO}_{2}$ efflux $[11,18]$ and then derived root respiration, but water content data were not available in our study. For beech [15], estimations of above-ground respiration at the stand level $\left(325 \mathrm{~g} \mathrm{C} \mathrm{m}^{-2}\right.$ year $\left.^{-1}\right)$ were very close to scaledup values derived from actual respiration measurements made at the tree level in the same experiment $[6,8]$. In the current study, to scale stand-level respiration estimations down to the tree level, we made the additional assumption that respiration was proportional to the crown projection area of trees. Given that foliar biomass is linearly related to crown projection area [26] and foliar respiration is proportional to foliar biomass, the above assumption seems plausible.

\subsection{Carbon budget}

The evaluation of the carbon budget of trees was intentionally considered for a one-year period comprising the current growing season (1995) and the period of time extending from the end of the preceding growing season (1994) to the beginning of the current one. In comparing the carbon balance to biomass increment, we assumed that carbon uptake during the growing 
Table VIII. Carbon balance for each of the two periods without growth during the one-year cycle considered, and carbon balance for the whole period without growth (Total) compared to the carbon allocated to foliage biomass production.

\begin{tabular}{|c|c|c|c|c|}
\hline \multirow[b]{2}{*}{ Tree } & \multicolumn{3}{|c|}{ Carbon balance $(\mathrm{kg} \mathrm{C})$} & \multirow{2}{*}{$\begin{array}{c}\text { Foliage } \\
\text { biomass } \\
(\mathrm{kg} \mathrm{C})\end{array}$} \\
\hline & $\begin{array}{c}\text { Period without } \\
\text { leaves (1) }\end{array}$ & $\begin{array}{l}\text { Period with leaves } \\
\text { but no growth (2) }\end{array}$ & $\begin{array}{c}\text { Total } \\
(1)+(2)\end{array}$ & \\
\hline 6 & 2.90 & -4.73 & -1.83 & 3.06 \\
\hline 10 & 1.71 & -2.27 & -0.55 & 1.19 \\
\hline 12 & 0.89 & -1.16 & -0.27 & 0.49 \\
\hline
\end{tabular}

(1) Period extending from the date of leaf collection (or complete leaf fall) in 1994 to the date of bud break in 1995: during this period, carbohydrates were used for respiration only.

(2) Period extending from the date when radial growth stopped for the 3 trees (approximately DOY 220) to the date of leaf collection (or complete leaf fall) in 1995: during this period, carbohydrates were partly stored and partly used for respiration. The carbon balance calculated for this period was used as an estimation of the carbon balance for the corresponding period in 1994

(1) + (2) This total gives an estimate of the carbon stored in the trees since growth stopped in 1994 and before leaves began to develop in spring 1995.

season was devoted to tree biomass increment and to storage of carbohydrates in the tree. In addition, we assumed that these carbohydrates were used exclusively for tree respiration during the dormant season and for the development of leaves at the beginning of the growing period. This assumption may be reliable given that leaves continue to photosynthesize well after growth ceases (approximately between DOY 220 and DOY 260 for trees 10 and 12 and between DOY 220 and DOY 300 for tree 6 , in 1995), even though the rate of photosynthesis decreases because of decreasing global radiation and temperature in late summer. Support for this assumption comes from the comparison between the carbon balance calculated for the period without growth (during the one-year cycle considered), and the carbon allocated to foliage production (Tab. VIII): the carbohydrates stored during the period without growth should be totally used for foliage production, the carbon missing being provided either by the carbohydrates stored during the previous years or by the photosynthesis of the foliage in development. In ring-porous species, like ash, the reserves accumulated at the end of the preceding growing season are used mainly in the spring of the following year [3, 21].

Gross assimilation $\left(A_{G}\right)$ was obtained from a calculated variable $\left(A_{N}\right)$ and estimated variables $\left(R_{E}\right.$ and $\left.R_{s r}\right)$. The differences in gross assimilation of sample trees are caused mainly by differences in total leaf area, and also by the distribution of leaves in the different crown layers because global radiation and, consequently, net assimilation vary among crown layers. These findings agree with those obtained for beech trees of similar age and crown status in the same region [24]. Therefore, the differences in the carbon balance $\left(C_{B}\right)$ of sample trees reflect the differences in gross assimilation.

\subsection{Biomass increment versus carbon balance}

Net productivity of the study trees, obtained from carbon fluxes, varies in the same way as the biomass increment obtained from tree growth measurements. The discrepancies observed between carbon balance and biomass increment at the tree level may be caused by the lack of some data (fine root production; true respiration of tree compartments). The assumptions made to estimate respiration for the study trees are probably the primary reason for these discrepancies: ash and beech do not have the same physiology, and the method of scaling stand respiration down to the tree level may be too simplistic. Further refinements of the respiration model could help to resolve these discrepancies. Another important source of uncertainty lies in the rough description of foliage distribution and in the relatively low sample rate for foliage and radiation in each crown layer.

Nevertheless, our findings are comparable to those obtained for beech trees sampled in the experimental stand where the relations for respiration, used here for ash, were established from flux measurements made at the stand level [24].

\section{CONCLUSION}

This study compared the biomass increment of trees (converted into carbon mass) with the carbon uptake derived from $\mathrm{CO}_{2}$ fluxes estimated at tree and stand levels. Although we conducted a detailed analysis of the biomass increment of the sample trees and a careful estimation of the carbon fluxes, many assumptions were necessary and these seem to have prevented us from obtaining closer agreement between the methods. These assumptions could be avoided with more intensive measurements, in which case it would be realistic to expect better estimations of the biomass increment of trees from $\mathrm{CO}_{2}$ flux measurements. Nonetheless, this study yielded new data concerning the allocation of biomass increment to different tree compartments, as a function of the competitive status of the trees.

On the basis of the results reported here, we may consider simulating carbon fluxes from micrometeorological data for the years of 1993 and 1994 and then comparing the growth and carbon balance of sample trees for years with differing climates. However, it would be necessary in this case to take into account other environmental factors, such as water availability, that can limit net assimilation of trees $[1,16]$.

This study is a first approach toward the future development of a mechanistic growth model for ash based on ecophysiological function [30]. Such a model would improve the current deterministic model for ash $[7,36]$ by allowing predictions of ash growth under different environmental conditions.

Acknowledgements: This study was conducted within the framework of a research program (A.I.P.) devoted to the study of the relations between structure, ecophysiology and growth of trees (supported by the INRA; 1993-1996). The authors wish to greatly thank L. Garros, R. Canta, G. Thiriet, B. Garnier and L. Le Goff for field and laboratory assistance with the various tree measurements, and P. Gross, B. Clerc and F. Willm for their assistance with the microclimatic and ecophysiological measurements. The authors are also indebted to the staff of the experimental farm "La Bouzule" near Nancy for their technical assistance in excavating the root systems, and to the Office National des Forêts (ONF Nancy) for allowing us to fell and cut the trees used in this study. We are also thankful to Elizabeth Gerson and to the two anonymous readers for their useful suggestions and comments that have substantially improved the clarity and precision of our manuscript. 


\section{REFERENCES}

[1] Arneth A., Kelliher F.M., McSeveny T.M., Byers J.N., Net ecosystem productivity, net primary productivity, and ecosystem carbon sequestration in a Pinus radiata plantation subject to soil water deficit, Tree Physiol. 18 (1998) 785-793.

[2] Baldocchi D.D., Harley P.C., Scaling carbon dioxide and water vapour exchange from leaf to canopy in a deciduous forest. II. Model testing and application, Plant Cell Environ. 18 (1995) 1157-1173.

[3] Barbaroux C., Bréda N., Contrasting distribution and seasonal dynamics of carbohydrate reserves in stem wood of adult ringporous sessile oak and diffuse-porous beech trees, Tree Physiol. 22 (2002) 1201-1210.

[4] Bartelink H.H., Allometric relationships for biomass and leaf area of beech (Fagus sylvatica L.), Ann. For. Sci. 54 (1997) 39-50.

[5] Cannell M.G.R., Physiological basis of wood production: a review, Scand. J. For. Res. 4 (1989) 459-490.

[6] Ceschia E., Damesin C., Lebaube S., Pontaillier J.-Y., Dufrêne E., Spatial and seasonal variations in stem respiration of beech trees (Fagus sylvatica L.), Ann. For. Sci. 59 (2002) 801-812.

[7] Cluzeau C., Le Goff N., Ottorini, J.-M., Development of primary branches and crown profile of Fraxinus excelsior L., Can. J. For Res. 24 (1994) 2315-2323.

[8] Damesin C., Ceschia E., Le Goff N., Ottorini J.-M., Dufrêne E., Stem and branch respiration of beech: from tree measurements to estimations at the stand level, New Phytol. 153 (2002) 159-172.

[9] Del Rio E., Berg A., Specific leaf area of Douglas-fir reproduction as affected by light and needle age, For. Sci. 25 (1979) 183-186.

[10] Epron D., Farque L., Lucot E., Badot P.M., Soil $\mathrm{CO}_{2}$ efflux in a beech forest: dependence on soil temperature and soil water content, Ann. For. Sci. 56 (1999) 221-226.

[11] Epron D., Ngao J., Granier A., Interannual variation of soil respiration in a beech forest ecosystem over a six-year study, Ann. For. Sci. 61 (2004) 499-505.

[12] Field C.B., Ball J.T., Berry J.A., Plant Physiological Ecology, Field methods and instrumentation, in: Pearcy R.W., Ehrlinger J., Mooney H.A., Rundel P.W. (Eds.), Photosynthesis: principles and field techniques, Chapman \& Hall, London, 1994, pp. 209-253.

[13] Flewelling J.W., Piennaar L.V., Multiplicative regression with lognormal errors, For. Sci. 27 (1981) 281-289.

[14] Gower S.T., Reich P.B., Son Y., Canopy dynamics and aboveground production of five tree species with different leaf longevities, Tree Physiol. 12 (1993) 327-345.

[15] Granier A., Ceschia E., Damesin C., Dufrêne E., Epron D., Gross P., Lebaube S., Le Dantec V., Le Goff N., Lemoine D., Lucot E., Ottorini J.M., Pontailler J.Y., Saugier B., The carbon balance of a young Beech forest, Funct. Ecol. 14 (2000) 312-325.

[16] Granier A., Damesin C., Epron D., Le Dantec V., Problématique du bilan de carbone dans les écosystèmes forestiers: exemple d'une jeune hêtraie de plaine, Schweiz. Z. Forstwes. 151 (2000) 317-324.

[17] Hinckley T.M., Aslin R.G., Aubuchon R.R., Metcalf C.L., Roberts J.E., Leaf conductance and photosynthesis in four species of the oak-hickory forest type, For. Sci. 24 (1978) 73-84.

[18] Joffre R., Ourcival J.-M., Rambal S., Rocheteau A., The key-role of topsoil moisture on $\mathrm{CO} 2$ efflux from a Mediterranean Quercus ilex forest, Ann. For. Sci. 60 (2003) 519-526.

[19] Kull O., Kruijt B., Leaf photosynthetic light response: a mechanistic model for scaling photosynthesis to leaves and canopies, Funct. Ecol. 12 (1998) 767-777.

[20] Kurz W.A., Beukema S.J., Apps M.J., Estimation of root biomass and dynamics for the carbon budget model of the Canadian forest sector, Can. J. For. Res. 26 (1996) 1973-1979.

[21] Lacointe A., Kajji A., Daudet F.-A., Archer P., Frossard J.S., Mobilization of carbon reserves in young walnut trees, Acta Bot. Gallica 140 (1993) 435-441.

[22] Landsberg J.J., Hingston F.J., Evaluating a simple radiation/dry matter conversion model using data from Eucalyptus globulus plantations in Western Australia, Tree Physiol. 16 (1997) 801-808.

[23] Larcher W., The carbon budget of the whole plant, in: Physiological plant ecology, 3rd ed., Springer-Verlag, Berlin, 1995, pp. 128-148.
[24] Lebaube S., Le Goff N., Ottorini J.-M., Granier A., Carbon balance and tree growth in a Fagus sylvatica stand, Ann. For. Sci. 57 (2000) 49-61.

[25] Lefèvre F., Laitat E., Medlyn B., Aubinet M., Carbon pools and annual carbon fluxes in the beech forest sub-plot at the Vielsalm pilot station, in: Ceulemans R.J.M., Veroustraete F., Gond V., Van Rensbergen J.B.H.F. (Eds.), Forest ecosystem modeling, upscaling and remote sensing, Academic Publishing, The Hague, The Netherlands, 2000, pp. 137-153.

[26] Le Goff N., Ottorini J.M., Leaf development and stem growth of ash (Fraxinus excelsior L.) as affected by tree competitive status, J. Appl. Ecol. 33 (1996) 793-802.

[27] Le Goff N., Ottorini J.M., Root biomass and biomass increment in a beech (Fagus sylvatica L.) stand in North-East France, Ann. For. Sci. 58 (2001) 1-13.

[28] Le Goff N., Ottorini J.M., Granier A., Peiffer M., Leaf development and light interception in ash (Fraxinus excelsior L.) trees of different social status in North-East France, Ann. For. Sci. (submitted).

[29] Le Roux X., Sinoquet H., Vandame M., Spatial distribution of leaf dry weight per area and leaf nitrogen concentration in relation to local radiation regime within an isolated tree crown, Tree Physiol. 19 (1999) 181-188

[30] Le Roux X., Lacointe A., Escobar-Guttiérrez A., Le Dizès S., Carbon-based models of individual tree growth: a critical appraisal, Ann. For. Sci. 58 (2001) 469-506.

[31] Matteucci G., De Angelis P., Dore S., Masci A., Valentini R., Scarascia Munozza G.E., Il bilanco del carbonio delle faggete: dall'albero all'ecosistema, in: Scarascia Mugnozza G.E. (Ed.), Ecologia strutturale e functionale di Faggete italiane, Edagricole, Bologna, Italy, 1999, pp. 133-183.

[32] Matthews G., The Carbon Content of Trees, Forestry Commission Technical Paper 4, Forestry Commission, Edimburgh, UK, 1993.

[33] Morecroft M.D., Roberts J.M., Photosynthesis and stomatal conductance of mature canopy Oak (Quercus robur) and Sycamore (Acer pseudoplatanus) trees throughout the growing season, Funct. Ecol. 13 (1999) 332-342.

[34] Noormets A., McDonald E.P., Dickson R.E., Kruger E.L., Sôber A., Isebrands J.G., Karnovsky D.F., The effect of elevated carbon dioxide and ozone on leaf- and branch-level photosynthesis and potential plant-level carbon gain in aspen, Trees 15 (2001) 262-270.

[35] Oren R., Waring R.H. Stafford S.G., Barrett J.W., Twenty-four years of ponderosa pine growth in relation to canopy leaf area and understory competition, For. Sci. 33 (1987) 538-547.

[36] Ottorini J.-M., Le Goff N., Cluzeau C., Relationships between crown dimensions and stem development in Fraxinus excelsior L., Can. J. For. Res. 26 (1996) 394-401.

[37] Rook D.A., Physiological constraints on yield, in: Tigerstedt M.A., Puttonen P., Koski V. (Eds.), Crop physiology of Forest Trees, Proceedings of an International Conference on Managing Forest Trees as Cultivated Plants, University of Helsinki, Helsinki, Finland, 1985, pp. $1-19$.

[38] Ryan M.G., Hubbard R.M., Pongracic S., Raison R.J., McMurtie R.E., Foliage, fine-root, woody tissue and stand respiration in Pinus radiata in relation to nitrogen status, Tree Physiol. 16 (1996) 333-343.

[39] Santa Regina I., Tarazona T., Calvo R., Aboveground biomass in a beech forest and a Scots pine plantation in the Sierra de la Demanda area of northern Spain, Ann. Sci. For. 54 (1997) 261-269.

[40] Satoo T., Madgwick H.A.I., Forest biomass, Martinus Nijhoff/Dr W. Junk Publishers, The Hague, The Netherlands, 1982.

[41] Shi K., Quang V.C., Predicted leaf area growth and foliage efficiency of loblolly pine plantations, For. Ecol. Manage. 95 (1997) 109-115.

[42] Thornley J.H.M., Mathematical Models in Plant Physiology, Academic Press, London, 1976.

[43] Waring R.H., Thies W.G., Muscato D., Stem growth per unit of leaf area: a measure of tree vigor, For. Sci. 26 (1980) 112-117.

[44] Waring R.H., Newman K., Bell J., Efficiency of tree crowns and stymied production at different canopy leaf densities, Forestry 54 (1981) 129-137.

[45] Waring R.H., Estimating forest growth and efficiency in relation to canopy leaf area, Adv. Ecol. Res. 13 (1983) 327-354. 